\title{
7. ABORIGINAL AND TORRES STRAIT ISLANDER MOTHERS AND BABIES
}

\section{Reporting of Aboriginality}

Maternal Aboriginality is under-reported on the MDC. One method of assessing the extent of under-reporting and monitoring changes over time is to compare the reporting of maternal Aboriginality to the MDC with reporting of maternal Aboriginality on birth registrations held by the NSW Registry of Births, Deaths and Marriages. Using capture-recapture methods, an estimate of the total number of babies born to Aboriginal mothers was obtained and compared with the number of babies born to Aboriginal mothers as reported to the MDC (Table 65). An estimate of the total number of babies born to Aboriginal mothers or fathers was also obtained and compared with the number of babies born to Aboriginal mothers as reported to the MDC
(Table 67). The method used here is described in Chapter 3 (page 14).

For NSW overall, the percentage of births to Aboriginal and Torres Strait Islander mothers reported to the MDC rose from 65.5 per cent to 69.3 per cent between 2002 and 2005 . In 2005, reporting varied markedly between area health services, ranging from 39.3 per cent in the Sydney South West Area to 86.8 per cent in the Greater Southern Area (Table 65, Figure 2). Under-reporting of Aboriginality on the MDC means that numbers of births presented in this chapter should be interpreted with caution. The total number of babies born to Aboriginal mothers in 2005 is estimated to be 3,614, about one-and-a half times higher than the number reported to the MDC.

\section{TABLE 65}

\begin{tabular}{|c|c|c|c|c|c|c|}
\hline $\begin{array}{l}\text { Year of birth - } \\
\text { Health area of } \\
\text { residence }\end{array}$ & $\begin{array}{c}\text { MDC } \\
\text { births } \\
\text { No. }\end{array}$ & $\begin{array}{c}\text { RBDM } \\
\text { births } \\
\text { No. }\end{array}$ & $\begin{array}{c}\text { Births reported } \\
\text { to both } \\
\text { MDC/RBDM } \\
\text { No. }\end{array}$ & $\begin{array}{l}\text { Total estimated } \\
\text { Aboriginal } \\
\text { births } \\
\text { No. }\end{array}$ & $\begin{array}{c}\text { Estimated } \\
\text { Aboriginal births } \\
\text { reported to MDC } \\
\%\end{array}$ & $\begin{array}{l}95 \% \text { confidence } \\
\text { interval of } \\
\text { estimated births } \\
\text { reported }\end{array}$ \\
\hline \multicolumn{7}{|l|}{2002} \\
\hline Sydney South West & 166 & 295 & 119 & 411 & 40.4 & $35.7-45.1$ \\
\hline $\begin{array}{l}\text { South Eastern Sydney \& Illa } \\
\text { warra }\end{array}$ & 175 & 187 & 105 & 311 & 56.2 & $50.7-61.8$ \\
\hline Sydney West & 208 & 301 & 141 & 443 & 46.9 & $42.3-51.5$ \\
\hline Northern Sydney \& Central Coast & 87 & 95 & 53 & 155 & 56.0 & $48.2-63.8$ \\
\hline Hunter \& New England & 520 & 421 & 317 & 690 & 75.3 & $72.1-78.5$ \\
\hline North Coast & 330 & 197 & 158 & 411 & 80.3 & $76.4-84.1$ \\
\hline Greater Southern & 160 & 114 & 87 & 209 & 76.4 & $70.7-82.2$ \\
\hline Greater Western & 524 & 335 & 297 & 591 & 88.7 & $86.1-91.2$ \\
\hline Other-not stated & 13 & 10 & 4 & 30 & 43.6 & $25.8-61.4$ \\
\hline NSW & 2183 & 1955 & 1281 & 3331 & 65.5 & $63.9-67.1$ \\
\hline \multicolumn{7}{|l|}{2003} \\
\hline Sydney South West & 161 & 285 & 95 & 482 & 33.4 & $29.2-37.6$ \\
\hline South Eastern Sydney \& Illawarra & 180 & 177 & 112 & 284 & 63.4 & $57.8-69.0$ \\
\hline Sydney West & 240 & 282 & 148 & 457 & 52.5 & $48.0-57.1$ \\
\hline Northern Sydney \& Central Coast & 83 & 108 & 61 & 147 & 56.6 & $48.6-64.6$ \\
\hline Hunter \& New England & 522 & 425 & 334 & 664 & 78.6 & $75.5-81.7$ \\
\hline North Coast & 311 & 175 & 139 & 391 & 79.5 & $75.5-83.5$ \\
\hline Greater Southern & 174 & 121 & 94 & 224 & 77.8 & $72.3-83.2$ \\
\hline Greater Western & 495 & 319 & 281 & 562 & 88.1 & $85.4-90.8$ \\
\hline Other-not stated & 23 & 16 & 13 & 28 & 81.7 & $67.4-96.0$ \\
\hline NSW & 2189 & 1908 & 1277 & 3270 & 66.9 & $65.3-68.5$ \\
\hline \multicolumn{7}{|l|}{2004} \\
\hline Sydney South West & 164 & 260 & 105 & 405 & 40.5 & $35.7-45.2$ \\
\hline South Eastern Sydney \& Illawarra & 224 & 203 & 136 & 334 & 67.1 & $62.0-72.1$ \\
\hline Sydney West & 242 & 271 & 151 & 434 & 55.8 & $51.1-60.5$ \\
\hline Northern Sydney \& Central Coast & 94 & 111 & 49 & 212 & 44.4 & $37.7-51.1$ \\
\hline Hunter \& New England & 514 & 416 & 306 & 699 & 73.6 & $70.3-76.9$ \\
\hline North Coast & 398 & 233 & 201 & 461 & 86.3 & $83.2-89.4$ \\
\hline Greater Southern & 175 & 142 & 94 & 264 & 66.3 & $60.6-72.0$ \\
\hline Greater Western & 506 & 274 & 245 & 566 & 89.4 & $86.9-92.0$ \\
\hline Other-not stated & 16 & 16 & 11 & 23 & 69.3 & $50.5-88.1$ \\
\hline NSW & 2333 & 1926 & 1298 & 3461 & 67.4 & $65.8-69.0$ \\
\hline
\end{tabular}




\begin{tabular}{|c|c|c|c|c|c|c|}
\hline \multicolumn{7}{|c|}{$\begin{array}{l}\text { BIRTHS TO ABORIGINAL MOTHERS BY SOURCE OF BIRTH REPORT, YEAR OF BIRTH AND HEALTH AREA OF } \\
\text { RESIDENCE, NSW 2002-2005 }\end{array}$} \\
\hline $\begin{array}{l}\text { Year of birth - } \\
\text { Health area of } \\
\text { residence }\end{array}$ & $\begin{array}{c}\text { MDC } \\
\text { births } \\
\text { No. }\end{array}$ & $\begin{array}{c}\text { RBDM } \\
\text { births } \\
\text { No. }\end{array}$ & $\begin{array}{c}\text { Births reported } \\
\text { to both } \\
\text { MDC/RBDM } \\
\text { No. }\end{array}$ & $\begin{array}{c}\text { Total estimated } \\
\text { Aboriginal } \\
\text { births } \\
\text { No. }\end{array}$ & $\begin{array}{c}\text { Estimated } \\
\text { Aboriginal births } \\
\text { reported to MDC } \\
\%\end{array}$ & $\begin{array}{l}95 \% \text { confidence } \\
\text { interval of } \\
\text { estimated births } \\
\text { reported }\end{array}$ \\
\hline \multicolumn{7}{|l|}{2005} \\
\hline Sydney South West & 163 & 189 & 74 & 414 & 39.3 & $34.6-44.0$ \\
\hline South Eastern Sydney \& Illawarra & 201 & 143 & 94 & 305 & 65.9 & $60.5-71.2$ \\
\hline Sydney West & 270 & 224 & 128 & 472 & 57.2 & $52.8-61.7$ \\
\hline Northern Sydney \& Central Coast & 88 & 93 & 43 & 189 & 46.5 & $39.4-53.6$ \\
\hline Hunter \& New England & 611 & 354 & 278 & 778 & 78.6 & $75.7-81.4$ \\
\hline North Coast & 357 & 152 & 124 & 437 & 81.7 & $78.0-85.3$ \\
\hline Greater Southern & 212 & 116 & 90 & 273 & 77.7 & $72.8-82.6$ \\
\hline Greater Western & 565 & 265 & 230 & 651 & 86.8 & $84.2-89.4$ \\
\hline Other-not stated & 39 & 26 & 22 & 46 & 84.9 & $74.5-95.2$ \\
\hline NSW & 2506 & 1562 & 1083 & 3614 & 69.3 & $67.8-70.8$ \\
\hline
\end{tabular}

\section{FIGURE 2}

LEVEL OF REPORTING OF ABORIGINALITY TO THE NSW MIDWIVES DATA COLLECTION BY YEAR OF BIRTH AND HEALTH AREA OF HOSPITAL, NSW 2002-2005

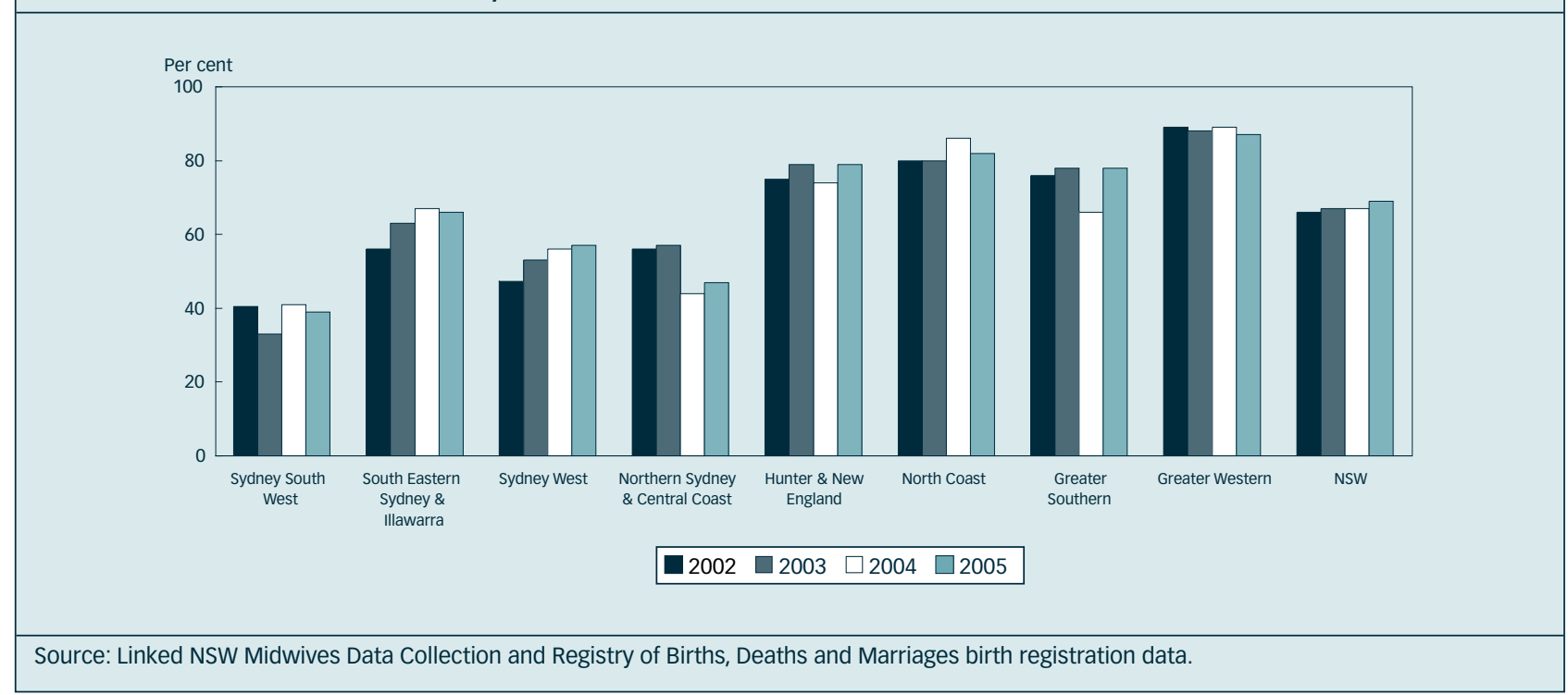

Information on paternal Aboriginality is not collected by the MDC, but is reported to the NSW Registry of Births, Deaths and Marriages. Of the 86,277 births registered for residents of NSW in 2005, 3,130 (3.6 per cent) were reported to have an Aboriginal or Torres Strait Islander mother or father (Table $66)$. For 1,182 babies, the mother was reported to be nonAboriginal or Torres Strait Islander and the father was reported to be Aboriginal or Torres Strait Islander.

\section{TABLE 66}

\section{BIRTH REGISTRATIONS BY MATERNAL AND PATERNAL INDIGENOUS STATUS, NSW 2005}

Mother

Aboriginal or Torres Strait Islander

Aboriginal or Torres Strait Islander

Non-Aboriginal

Non-Aboriginal

TOTAL

\section{Father}

Aboriginal or Torres Strait Islander

Non-Aboriginal

Aboriginal or Torres Strait Islander

Non-Aboriginal

$\begin{array}{|rr|}\text { No. } & \% \\ 581 & 0.7 \\ 1367 & 1.6 \\ 1182 & 1.4 \\ 83147 & 96.4 \\ 86277 & 100.0\end{array}$

Source: Australian Bureau of Statistics birth registration data (HOIST), Centre for Epidemiology and Research, NSW Department of Health. Births registered among NSW residents. Births where indigenous status was not stated were classified as non-Aboriginal. 
Table 67 shows the number of babies born to Aboriginal mothers as reported to the MDC and the number of babies born to Aboriginal mothers or fathers as reported to the NSW Registry of Births, Deaths and Marriages between 2002 and 2005. Using capture-recapture methods, an estimate of the total number of babies born to Aboriginal mothers or fathers was obtained from both data sources. For NSW overall, the percentage of births to Aboriginal and
Torres Strait Islander mothers or fathers that are reported to the MDC rose slightly from 42.2 per cent to 43.7 per cent between 2002 and 2005. In 2005, this percentage ranged from 25.0 per cent in the Sydney South West Area to 57.3 per cent in the Greater Southern Area (Table 67).

There are therefore a substantial number of babies with non-indigenous mothers and indigenous fathers who are not represented in the numbers reported in this chapter.

\section{TABLE 67}

BIRTHS TO ABORIGINAL MOTHERS AND FATHERS BY SOURCE OF BIRTH REPORT, YEAR OF BIRTH AND HEALTH AREA OF RESIDENCE, NSW 2002-2005

\begin{tabular}{|c|c|c|c|c|c|c|}
\hline $\begin{array}{l}\text { Year of birth - } \\
\text { Heath area of } \\
\text { residence }\end{array}$ & $\begin{array}{c}\text { MDC } \\
\text { births } \\
\text { No. }\end{array}$ & $\begin{array}{c}\text { RBDM } \\
\text { births } \\
\\
\text { No. }\end{array}$ & $\begin{array}{c}\text { Births reported } \\
\text { to both } \\
\text { MDC/RBDM } \\
\text { No. }\end{array}$ & $\begin{array}{c}\text { Total } \\
\text { estimated } \\
\text { Aboriginal } \\
\text { births }\end{array}$ & $\begin{array}{c}\text { Estimated } \\
\text { Aboriginal births } \\
\text { reported to MDC } \\
\%\end{array}$ & $\begin{array}{l}\text { 95\% confidence } \\
\text { interval of } \\
\text { estimated births } \\
\text { reported }\end{array}$ \\
\hline \multicolumn{7}{|l|}{2002} \\
\hline Sydney South West & 166 & 442 & 120 & 610 & 27.2 & $23.7-30.7$ \\
\hline South Eastern Sydney \& Illawarra & 175 & 327 & 110 & 519 & 33.7 & $29.6-37.8$ \\
\hline Sydney West & 208 & 469 & 143 & 681 & 30.5 & $27.1-34.0$ \\
\hline Northern Sydney \& Central Coast & 87 & 175 & 57 & 266 & 32.7 & $27.1-38.3$ \\
\hline Hunter \& New England & 520 & 663 & 326 & 1057 & 49.2 & $46.2-52.2$ \\
\hline North Coast & 330 & 342 & 163 & 691 & 47.7 & $44.0-51.5$ \\
\hline Greater Southern & 160 & 213 & 92 & 369 & 43.3 & $38.3-48.4$ \\
\hline Greater Western & 524 & 485 & 307 & 827 & 63.3 & $60.0-66.6$ \\
\hline Other-not stated & 13 & 17 & 4 & 49 & 26.3 & $14.0-38.6$ \\
\hline NSW & 2183 & 3133 & 1322 & 5173 & 42.2 & $40.9-43.5$ \\
\hline \multicolumn{7}{|l|}{2003} \\
\hline Sydney South West & 161 & 428 & 97 & 708 & 22.7 & $19.6-25.8$ \\
\hline South Eastern Sydney \& Illawarra & 180 & 312 & 115 & 487 & 36.9 & $32.6-41.2$ \\
\hline Sydney West & 240 & 466 & 152 & 735 & 32.7 & $29.3-36.1$ \\
\hline Northern Sydney \& Central Coast & 83 & 183 & 64 & 237 & 35.1 & $29.0-41.1$ \\
\hline Hunter \& New England & 522 & 664 & 339 & 1022 & 51.1 & $48.0-54.1$ \\
\hline North Coast & 311 & 291 & 145 & 623 & 49.9 & $46.0-53.8$ \\
\hline Greater Southern & 174 & 211 & 97 & 378 & 46.1 & $41.1-51.1$ \\
\hline Greater Western & 495 & 491 & 288 & 843 & 58.7 & $55.4-62.0$ \\
\hline Other-not stated & 23 & 28 & 14 & 45 & 50.7 & $36.1-65.2$ \\
\hline NSW & 2189 & 3074 & 1311 & 5132 & 42.7 & $41.3-44.0$ \\
\hline \multicolumn{7}{|l|}{2004} \\
\hline Sydney South West & 164 & 395 & 109 & 593 & 27.7 & $24.1-31.3$ \\
\hline South Eastern Sydney \& Illawarra & 224 & 344 & 139 & 553 & 40.5 & $36.4-44.6$ \\
\hline Sydney West & 242 & 454 & 151 & 726 & 33.3 & $29.9-36.7$ \\
\hline Northern Sydney \& Central Coast & 94 & 214 & 51 & 392 & 24.0 & $19.8-28.2$ \\
\hline Hunter \& New England & 514 & 653 & 310 & 1082 & 47.5 & $44.5-50.5$ \\
\hline North Coast & 398 & 353 & 212 & 662 & 60.1 & $56.4-63.8$ \\
\hline Greater Southern & 175 & 231 & 97 & 416 & 42.1 & $37.4-46.8$ \\
\hline Greater Western & 506 & 418 & 255 & 829 & 61.1 & $57.7-64.4$ \\
\hline Other-not stated & 16 & 25 & 11 & 36 & 44.7 & $28.4-60.9$ \\
\hline NSW & 2333 & 3087 & 1335 & 5394 & 43.3 & $41.9-44.6$ \\
\hline \multicolumn{7}{|l|}{2005} \\
\hline Sydney South West & 163 & 310 & 77 & 653 & 25.0 & $21.6-28.3$ \\
\hline South Eastern Sydney \& Illawarra & 201 & 268 & 97 & 553 & 36.3 & $32.3-40.3$ \\
\hline Sydney West & 270 & 372 & 133 & 753 & 35.8 & $32.4-39.3$ \\
\hline Northern Sydney \& Central Coast & 88 & 162 & 44 & 321 & 27.4 & $22.5-32.3$ \\
\hline Hunter \& New England & 611 & 584 & 289 & 1234 & 49.5 & $46.7-52.3$ \\
\hline North Coast & 357 & 257 & 132 & 693 & 51.5 & $47.8-55.2$ \\
\hline Greater Southern & 212 & 180 & 96 & 396 & 53.5 & $48.6-58.4$ \\
\hline Greater Western & 565 & 412 & 236 & 985 & 57.3 & $54.3-60.4$ \\
\hline Other-not stated & 39 & 33 & 22 & 58 & 67.1 & $55.0-79.2$ \\
\hline NSW & 2506 & 2578 & 1126 & 5736 & 43.7 & $42.4-45.0$ \\
\hline
\end{tabular}




\section{Trends in births}

In 2006, 2,463 babies were born to Aboriginal mothers,

135 babies were born to mothers of both Aboriginal and 51 babies were born to Torres Strait Islander mothers and

Torres Strait Islander background (Table 68).

\begin{tabular}{|c|c|c|c|c|c|c|c|c|c|c|}
\hline \multirow[t]{3}{*}{ Indigenous status } & \multicolumn{10}{|c|}{ Year } \\
\hline & \multicolumn{2}{|c|}{2002} & \multicolumn{2}{|c|}{2003} & \multicolumn{2}{|c|}{2004} & \multicolumn{2}{|c|}{2005} & \multicolumn{2}{|c|}{2006} \\
\hline & No. & $\%$ & No. & $\%$ & No. & $\%$ & No. & $\%$ & No. & $\%$ \\
\hline \multicolumn{11}{|l|}{ Confinements } \\
\hline Aboriginal but not Torres Straight Islander & 2041 & 94.7 & 2014 & 93.2 & 2161 & 93.6 & 2347 & 94.9 & 2429 & 93.0 \\
\hline Torres Strait Islander but not Aboriginal & 25 & 1.2 & 35 & 1.6 & 48 & 2.1 & 30 & 1.2 & 50 & 1.9 \\
\hline Both Aboriginal and Torres Strait Islander & 89 & 4.1 & 112 & 5.2 & 99 & 4.3 & 97 & 3.9 & 132 & 5.1 \\
\hline TOTAL & 2155 & 100.0 & 2161 & 100.0 & 2308 & 100.0 & 2474 & 100.0 & 2611 & 100.0 \\
\hline \multicolumn{11}{|l|}{ Births } \\
\hline \multicolumn{11}{|l|}{ Aboriginal but not Torres } \\
\hline Straight Islander & 2069 & 94.8 & 2039 & 93.1 & 2184 & 93.6 & 2376 & 94.8 & 2463 & 93.0 \\
\hline Torres Strait Islander but not Aboriginal & 25 & 1.1 & 37 & 1.7 & 48 & 2.1 & 31 & 1.2 & 51 & 1.9 \\
\hline Both Aboriginal and Torres Strait Islander & 89 & 4.1 & 114 & 5.2 & 101 & 4.3 & 100 & 4.0 & 135 & 5.1 \\
\hline TOTAL & 2183 & 100.0 & 2190 & 100.0 & 2333 & 100.0 & 2507 & 100.0 & 2649 & 100.0 \\
\hline
\end{tabular}

\section{Plurality}

Between 2002 and 2006, the reported number of babies born to Aboriginal and Torres Strait Islander mothers increased from 2,183 to 2,649 (Table 69), representing 2.5 and 2.9 per cent respectively of all babies born in NSW. Multiple pregnancies (twins, triplets etc.) were reported for about one per cent of mothers.

\begin{tabular}{|c|c|c|c|c|c|c|c|c|c|c|}
\hline \multirow[t]{3}{*}{ Plurality } & \multicolumn{10}{|c|}{ Year } \\
\hline & \multicolumn{2}{|c|}{2002} & \multicolumn{2}{|c|}{2003} & \multicolumn{2}{|c|}{2004} & \multicolumn{2}{|c|}{2005} & \multicolumn{2}{|c|}{2006} \\
\hline & No. & $\%$ & No. & $\%$ & No. & $\%$ & No. & $\%$ & No. & $\%$ \\
\hline \multicolumn{11}{|c|}{ Confinements } \\
\hline Singleton & 2127 & 98.7 & 2134 & 98.8 & 2283 & 98.9 & 2443 & 98.7 & 2574 & 98.6 \\
\hline Twins & 28 & 1.3 & 26 & 1.2 & 25 & 1.1 & 29 & 1.2 & 36 & 1.4 \\
\hline Triplets & 0 & 0.0 & 1 & 0.0 & 0 & 0.0 & 2 & 0.1 & 1 & 0.0 \\
\hline TOTAL & 2155 & 100.0 & 2161 & 100.0 & 2308 & 100.0 & 2474 & 100.0 & 2611 & 100.0 \\
\hline \multicolumn{11}{|l|}{ Births } \\
\hline \multicolumn{11}{|l|}{ Singleton } \\
\hline Twins & 2127 & 97.4 & 2134 & 97.4 & 2283 & 97.9 & 2443 & 97.4 & 2574 & 97.2 \\
\hline Triplets & 56 & 2.6 & 53 & 2.4 & 50 & 2.1 & 58 & 2.3 & 72 & 2.7 \\
\hline TOTAL & 2183 & 100.0 & 2190 & 100.0 & 2333 & 100.0 & 2507 & 100.0 & 2649 & 100.0 \\
\hline
\end{tabular}

Source: NSW Midwives Data Collection, Centre for Epidemiology and Research, NSW Department of Health.

\# Due to under-reporting of Aboriginality to the MDC, it is likely that the true numbers of confinements are about one-and-a-half times higher than shown, and the numbers of births are about two times higher than shown. 


\section{Previous pregnancies}

In 2006, about one-third of Aboriginal and Torres Strait Islander mothers gave birth for the first time (Table 70), about 60 per cent of mothers reported between one and 4 previous births and 7.6 per cent of mothers had given birth to 5 or more babies. This pattern has not changed substantially since 2002.

\section{TABLE 70}

\section{PREVIOUS PREGANCIES AMONG ABORIGINAL AND TORRES STRAIT ISLANDER MOTHERS, NSW 2002-2006\#}

No. previous pregnancies ( $>20$ weeks)

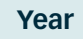

\begin{tabular}{|c|c|c|c|c|c|c|c|c|c|c|}
\hline \multirow[t]{2}{*}{ ( } & \multicolumn{2}{|c|}{2002} & \multicolumn{2}{|c|}{2003} & \multicolumn{2}{|c|}{2004} & \multicolumn{2}{|c|}{2005} & \multicolumn{2}{|c|}{2006} \\
\hline & No. & $\%$ & No. & $\%$ & No. & $\%$ & No. & $\%$ & No. & $\%$ \\
\hline 0 & 664 & 30.8 & 668 & 30.9 & 759 & 32.9 & 787 & 31.8 & 844 & 32.3 \\
\hline $1-4$ & 1302 & 60.4 & 1316 & 60.9 & 1327 & 57.5 & 1472 & 59.5 & 1551 & 59.4 \\
\hline $5+$ & 183 & 8.5 & 177 & 8.2 & 221 & 9.6 & 214 & 8.6 & 199 & 7.6 \\
\hline Not stated & 6 & 0.3 & 0 & 0.0 & 1 & 0.0 & 1 & 0.0 & 17 & 0.7 \\
\hline TOTAL & 2155 & 100.0 & 2161 & 100.0 & 2308 & 100.0 & 2474 & 100.0 & 2611 & 100.0 \\
\hline
\end{tabular}

\section{Maternal age}

The reported number of babies born to Aboriginal and Torres Strait Islander mothers has increased at all ages. About one in 5 Aboriginal and Torres Strait Islander mothers were teenagers in 2006. Following state-wide trends, the number of mothers giving birth at 35 years of age or more has increased over the last 5 years - from 6.8 per cent in 2002 to 8.5 per cent in 2006 (Table 71).

\section{TABLE 71}

AGE OF ABORIGINAL AND TORRES STRAIT ISLANDER MOTHERS, NSW 2002-2006\#

Maternal age (years) Year

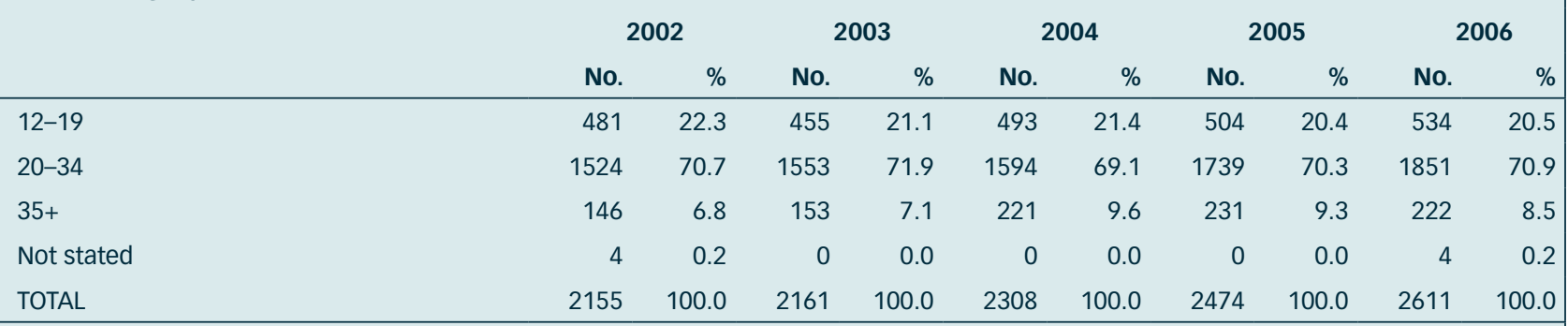

Source: NSW Midwives Data Collection, Centre for Epidemiology and Research, NSW Department of Health.

\# Due to under-reporting of Aboriginality to the MDC, it is likely that the true numbers are about one-and-a-half times higher than shown. 


\section{Health area of residence}

The reported number of Aboriginal and Torres Strait Islander mothers who gave birth in 2006 ranged from 105 in the Northern Sydney and Central Coast Area to 594 in the Hunter and New England Area (Table 72).
The proportion of mothers who were teenagers varied from 14.6 cent in the Sydney South West Area to 24.4 per cent in the Greater Western Area (Table 73).

\section{TABLE 72}

\begin{tabular}{|c|c|c|c|c|c|c|c|c|c|c|}
\hline \multirow[t]{3}{*}{ Health Area } & \multicolumn{10}{|c|}{ Year } \\
\hline & \multicolumn{2}{|c|}{2002} & \multicolumn{2}{|c|}{2003} & \multicolumn{2}{|c|}{2004} & \multicolumn{2}{|c|}{2005} & \multicolumn{2}{|c|}{2006} \\
\hline & No. & $\%$ & No. & $\%$ & No. & $\%$ & No. & $\%$ & No. & $\%$ \\
\hline Sydney South West & 165 & 7.7 & 160 & 7.4 & 164 & 7.1 & 181 & 7.3 & 213 & 8.2 \\
\hline South Eastern Sydney \& Illawarra & 173 & 8.0 & 178 & 8.2 & 221 & 9.6 & 198 & 8.0 & 228 & 8.7 \\
\hline Sydney West & 204 & 9.5 & 237 & 11.0 & 238 & 10.3 & 269 & 10.9 & 284 & 10.9 \\
\hline Northern Sydney \& Central Coast & 85 & 3.9 & 82 & 3.8 & 93 & 4.0 & 88 & 3.6 & 105 & 4.0 \\
\hline Hunter \& New England & 513 & 23.8 & 514 & 23.8 & 508 & 22.0 & 600 & 24.3 & 594 & 22.7 \\
\hline North Coast & 327 & 15.2 & 304 & 14.1 & 390 & 16.9 & 350 & 14.1 & 406 & 15.5 \\
\hline Greater Southern & 158 & 7.3 & 170 & 7.9 & 173 & 7.5 & 209 & 8.4 & 193 & 7.4 \\
\hline Greater Western & 517 & 24.0 & 493 & 22.8 & 505 & 21.9 & 560 & 22.6 & 561 & 21.5 \\
\hline Other/Not stated & 13 & 0.6 & 23 & 1.1 & 16 & 0.7 & 19 & 0.8 & 27 & 1.0 \\
\hline TOTAL & 2155 & 100.0 & 2161 & 100.0 & 2308 & 100.0 & 2474 & 100.0 & 2611 & 100.0 \\
\hline
\end{tabular}

Source: NSW Midwives Data Collection, Centre for Epidemiology and Research, NSW Department of Health.

\# Due to under-reporting of Aboriginality to the MDC, it is likely that the true numbers for the total are about one-and-a-half times higher than shown. The level of under-reporting varies between health areas (Table 65).

\section{TABLE 73}

\section{HEALTH AREA OF RESIDENCE OF ABORIGINAL AND TORRES STRAIT ISLANDER MOTHERS BY AGE, NSW 2006\#}

\begin{tabular}{|c|c|c|c|c|c|c|c|c|}
\hline \multirow[t]{3}{*}{ Health Area } & \multicolumn{8}{|c|}{ Maternal age (years) } \\
\hline & \multicolumn{2}{|c|}{ Under 20} & \multicolumn{2}{|c|}{ 20-plus } & \multicolumn{2}{|c|}{ Not stated } & \multicolumn{2}{|c|}{ TOTAL } \\
\hline & No. & $\%$ & No. & $\%$ & No. & $\%$ & No. & $\%$ \\
\hline Sydney South West & 31 & 14.6 & 182 & 85.4 & 0 & 0.0 & 213 & 100.0 \\
\hline South Eastern Sydney \& Illawarra & 38 & 16.7 & 189 & 82.9 & 1 & 0.4 & 228 & 100.0 \\
\hline Sydney West & 51 & 18.0 & 233 & 82.0 & 0 & 0.0 & 284 & 100.0 \\
\hline Northern Sydney \& Central Coast & 23 & 21.9 & 82 & 78.1 & 0 & 0.0 & 105 & 100.0 \\
\hline Hunter \& New England & 127 & 21.4 & 467 & 78.6 & 0 & 0.0 & 594 & 100.0 \\
\hline North Coast & 79 & 19.5 & 327 & 80.5 & 0 & 0.0 & 406 & 100.0 \\
\hline Greater Southern & 42 & 21.8 & 151 & 78.2 & 0 & 0.0 & 193 & 100.0 \\
\hline Greater Western & 137 & 24.4 & 421 & 75.0 & 3 & 0.5 & 561 & 100.0 \\
\hline Other/Not stated & 6 & 22.2 & 21 & 77.8 & 0 & 0.0 & 27 & 100.0 \\
\hline TOTAL & 534 & 20.5 & 2073 & 79.4 & 4 & 0.2 & 2611 & 100.0 \\
\hline
\end{tabular}

Source: NSW Midwives Data Collection, Centre for Epidemiology and Research, NSW Department of Health.

\# Due to under-reporting of Aboriginality to the MDC, it is likely that the true numbers for the total are about one-and-a-half times higher than shown. The level of under-reporting varies between health areas (Table 65). 


\section{Booking status}

In 2006, 89.1 per cent of Aboriginal and Torres Strait Islander mothers were booked into the hospital of birth, a rise from 87.3 per cent in 2002. In 2006, 94.8 per cent of non-Aboriginal or Torres Strait Islander mothers were booked into the hospital of birth.

\section{Duration of pregnancy at first antenatal visit}

Between 2002 and 2006, the proportion of Aboriginal or Torres Strait Islander mothers who commenced antenatal care at less than 20 weeks gestation rose from 67.2 to 74.8 per cent (Table 74). This compares with 87.9 per cent of nonAboriginal or Torres Strait Islander mothers who commenced antenatal care at less than 20 weeks gestation in 2006.

In 2006, the proportion of Aboriginal and Torres Strait Islander mothers who commenced antenatal care at less than 20 weeks gestation varied from 63.4 per cent in the Sydney South West Area to 84.8 per cent in the Northern Sydney and Central Coast Area (Table 75).

\section{TABLE 74}

\section{DURATION OF PREGNANCY AT FIRST ANTENATAL VISIT AMONG ABORIGINAL AND TORRES STRAIT ISLANDER}

MOTHERS, NSW 2002-2006\#

\begin{tabular}{|c|c|c|c|c|c|c|c|c|c|c|}
\hline \multirow[t]{3}{*}{ Duration of pregnancy (weeks) } & \multicolumn{10}{|c|}{ Year } \\
\hline & \multicolumn{2}{|c|}{2002} & \multicolumn{2}{|c|}{2003} & \multicolumn{2}{|c|}{2004} & \multicolumn{2}{|c|}{2005} & \multicolumn{2}{|c|}{2006} \\
\hline & No. & $\%$ & No. & $\%$ & No. & $\%$ & No. & $\%$ & No. & $\%$ \\
\hline 0-19 & 1448 & 67.2 & 1526 & 70.6 & 1618 & 70.1 & 1854 & 74.9 & 1952 & 74.8 \\
\hline $20+$ & 560 & 26.0 & 547 & 25.3 & 573 & 24.8 & 561 & 22.7 & 550 & 21.1 \\
\hline Not stated & 147 & 6.8 & 88 & 4.1 & 117 & 5.1 & 59 & 2.4 & 109 & 4.2 \\
\hline TOTAL & 2155 & 100.0 & 2161 & 100.0 & 2308 & 100.0 & 2474 & 100.0 & 2611 & 100.0 \\
\hline
\end{tabular}

Source: NSW Midwives Data Collection, Centre for Epidemiology and Research, NSW Department of Health.

\# Due to under-reporting of Aboriginality to the MDC, it is likely that the true numbers are about one-and-a-half times higher than shown.

\section{TABLE 75}

DURATION OF PREGNANCY AT FIRST ANTENATAL VISIT AMONG ABORIGINAL AND TORRES STRAIT ISLANDER MOTHERS BY HEALTH AREA OF RESIDENCE, NSW 2006\#

Health Area

Duration of pregnancy (weeks)

\begin{tabular}{|c|c|c|c|c|c|c|c|c|}
\hline & & & & & Not & & & AL \\
\hline & No. & $\%$ & No. & $\%$ & No. & $\%$ & No. & $\%$ \\
\hline Sydney South West & 135 & 63.4 & 64 & 30.0 & 14 & 6.6 & 213 & 100.0 \\
\hline South Eastern Sydney \& Illawarra & 179 & 78.5 & 45 & 19.7 & 4 & 1.8 & 228 & 100.0 \\
\hline Sydney West & 217 & 76.4 & 65 & 22.9 & 2 & 0.7 & 284 & 100.0 \\
\hline Northern Sydney \& Central Coast & 89 & 84.8 & 16 & 15.2 & 0 & 0.0 & 105 & 100.0 \\
\hline Hunter \& New England & 437 & 73.6 & 140 & 23.6 & 17 & 2.9 & 594 & 100.0 \\
\hline North Coast & 311 & 76.6 & 76 & 18.7 & 19 & 4.7 & 406 & 100.0 \\
\hline Greater Southern & 148 & 76.7 & 37 & 19.2 & 8 & 4.1 & 193 & 100.0 \\
\hline Greater Western & 412 & 73.4 & 105 & 18.7 & 44 & 7.8 & 561 & 100.0 \\
\hline Other/Not stated & 24 & 88.9 & 2 & 7.4 & 1 & 3.7 & 27 & 100.0 \\
\hline TOTAL & 1952 & 74.8 & 550 & 21.1 & 109 & 4.2 & 2611 & 100.0 \\
\hline
\end{tabular}

Source: NSW Midwives Data Collection, Centre for Epidemiology and Research, NSW Department of Health.

\# Information not shown for Health Areas where the number of mothers is less than 5 in a group.

\# Due to under-reporting of Aboriginality to the MDC, it is likely that the true numbers are about one-and-a-half times higher than shown.

The level of under-reporting varies between health areas (Table 65). 


\section{Smoking in pregnancy}

In 2006, 53.6 per cent of Aboriginal and Torres Strait Islander mothers reported smoking at some time during pregnancy, compared to 58.0 per cent in 2002. This compares with 12.3 per cent of non-Aboriginal or Torres Strait Islander mothers who reported smoking at some time during pregnancy in 2006.
Smoking in the second half of pregnancy poses the greatest risk to the health of both mother and baby. In 2006, 52.3 per cent of Aboriginal and Torres Strait Islander mothers reported smoking in the second half of pregnancy. This percentage varied from 40.4 per cent in the Sydney South West Area to 59.7 per cent in the Greater Western Area (Figure 3).

\section{FIGURE 3}

\section{SMOKING IN THE SECOND HALF OF PREGNANCY AMONG ABORIGINAL AND TORRES STRAIT ISLANDER MOTHERS BY AMOUNT SMOKED AND HEALTH AREA OF RESIDENCE, NSW 2006\#}

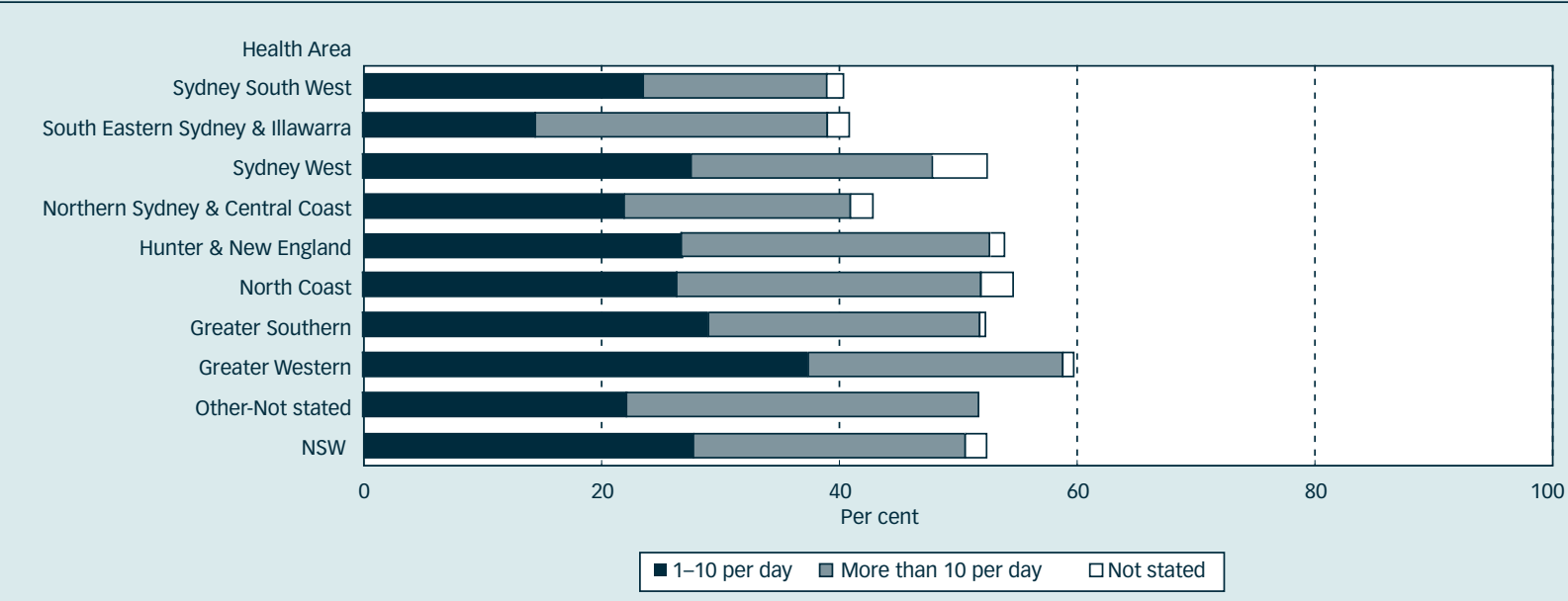

Source: NSW Midwives Data Collection (HOIST). Centre for Epidemiology and Research. NSW Department of Health.

\# Due to under-reporting of Aboriginality to the MDC, it is likely that the true numbers for NSW are about one and a half times higher than shown. The level of reporting varies between areas (Table 65).

\section{Medical conditions and obstetric complications}

In 2006, there was a slightly lower rate of gestational diabetes reported among Aboriginal and Torres Strait Islander mothers compared with non-Aboriginal or Torres Strait Islander mothers (Table 76). The number of Aboriginal and Torres Strait Islander mothers with medical conditions and obstetric complications reported to the MDC is low, even after taking into account underreporting of maternal Aboriginality. This is particularly the case for diabetes. The low numbers may be due to under-detection and/or under-reporting.

\section{TABLE 76}

\begin{tabular}{|c|c|c|c|c|c|c|c|c|}
\hline \multirow[t]{3}{*}{ Condition } & \multicolumn{8}{|c|}{ Aboriginality } \\
\hline & \multicolumn{2}{|c|}{$\begin{array}{l}\text { Aboriginal/ Torres } \\
\text { Strait islander }\end{array}$} & \multicolumn{2}{|c|}{$\begin{array}{l}\text { Non-Aboriginal/ } \\
\text { Torres Strait islander }\end{array}$} & \multicolumn{2}{|c|}{ Not stated } & \multicolumn{2}{|c|}{ TOTAL } \\
\hline & No. & $\%$ & No. & $\%$ & No. & $\%$ & No. & $\%$ \\
\hline Diabetes mellitus & 29 & 1.1 & 508 & 0.6 & 4 & 0.8 & 541 & 0.6 \\
\hline Gestational diabetes & 102 & 3.9 & 4255 & 4.8 & 18 & 3.4 & 4375 & 4.8 \\
\hline Essential hypertension & 17 & 0.7 & 785 & 0.9 & 2 & 0.4 & 804 & 0.9 \\
\hline Pre-eclampsia & 137 & 5.2 & 4287 & 4.9 & 12 & 2.3 & 4436 & 4.9 \\
\hline TOTAL CONFINEMENTS & 2611 & 100.0 & 88176 & 100.0 & 528 & 100.0 & 91315 & 100.0 \\
\hline
\end{tabular}




\section{Labour and birth}

The rate of spontaneous onset of labour fell from 69.9 per cent in 2002 to 66.2 per cent in 2006 (Table 77), while the rate of induction of labour among Aboriginal and Torres Strait Islander mothers increased marginally from about 19 to 21 per cent. The rate of induction of labour among Aboriginal and Torres Strait Islander mothers was slightly lower than the rate of 24.8 per cent reported among nonAboriginal and Torres Strait Islander mothers in 2006.
Between 2002 and 2006, the rate of normal vaginal birth fell from 74.2 to 71.5 per cent. The caesarean section rate rose from 20.6 to 22.5 per cent (Table 78 ). The rate of forceps delivery remained stable at about 2 per cent, and vaginal breech birth was about 1 per cent.

\section{TABLE 77}

\begin{tabular}{|c|c|c|c|c|c|c|c|c|c|c|}
\hline \multirow[t]{3}{*}{ Labour onset } & \multicolumn{10}{|c|}{ Year } \\
\hline & \multicolumn{2}{|c|}{2002} & \multicolumn{2}{|c|}{2003} & \multicolumn{2}{|c|}{2004} & \multicolumn{2}{|c|}{2005} & \multicolumn{2}{|c|}{2006} \\
\hline & No. & $\%$ & No. & $\%$ & No. & $\%$ & No. & $\%$ & No. & $\%$ \\
\hline Spontaneous & 1507 & 69.9 & 1469 & 68.0 & 1581 & 68.5 & 1613 & 65.2 & 1728 & 66.2 \\
\hline No labour\#\# & 223 & 10.3 & 250 & 11.6 & 260 & 11.3 & 277 & 11.2 & 329 & 12.6 \\
\hline Induced & 423 & 19.6 & 442 & 20.5 & 467 & 20.2 & 584 & 23.6 & 552 & 21.1 \\
\hline Not stated & 2 & 0.1 & 0 & 0.0 & 0 & 0.0 & 0 & 0.0 & 2 & 0.1 \\
\hline TOTAL & 2155 & 100.0 & 2161 & 100.0 & 2308 & 100.0 & 2474 & 100.0 & 2611 & 100.0 \\
\hline
\end{tabular}

Source: NSW Midwives Data Collection, Centre for Epidemiology and Research, NSW Department of Health.

\# Due to under-reporting of Aboriginality to the MDC, it is likely that the true numbers are about one-and-a-half times higher than shown.

\#\# No labour indicates elective caesarean section.

\section{TABLE 78}

TYPE OF BIRTH AMONG ABORIGINAL AND TORRES STRAIT ISLANDER MOTHERS, NSW 2002-2006\#

Type of birth Year

$\begin{array}{rrrrrr}2002 & 2003 & 2004 & 2005 & 2006\end{array}$

Normal vaginal

$\begin{array}{rrrrrrrrrr}\text { No. } & \% & \text { No. } & \% & \text { No. } & \% & \text { No. } & \% & \text { No. } & \% \\ 1598 & 74.2 & 1585 & 73.3 & 1647 & 71.4 & 1741 & 70.4 & 1868 & 71.5\end{array}$

Forceps

Vacuum extraction

$\begin{array}{llllllllll}30 & 1.4 & 35 & 1.6 & 60 & 2.6 & 42 & 1.7 & 46 & 1.8\end{array}$

Vaginal breech

Elective caesarean section

$\begin{array}{llllllllll}68 & 3.2 & 67 & 3.1 & 74 & 3.2 & 91 & 3.7 & 84 & 3.2\end{array}$

$\begin{array}{llll}14 & 0.6 & 9 & 0.4\end{array}$

Emergency caesarean section\#\#

$223 \quad 10.3$

$250 \quad 11.6$

$\begin{array}{llll}16 & 0.7 & 24 & 1.0\end{array}$

17

Not stated

TOTAL

$\begin{array}{llll}0 & 0.0 & 0 & 0.0\end{array}$

260

$11.3 \quad 277 \quad 11.2$

329

251

10.9

$299 \quad 12.1$

$\begin{array}{llllllllll}2155 & 100.0 & 2161 & 100.0 & 2308 & 100.0 & 2474 & 100.0 & 2611 & 100.0\end{array}$

Source: NSW Midwives Data Collection, Centre for Epidemiology and Research, NSW Department of Health.

\# Due to under-reporting of Aboriginality to the MDC, it is likely that the true numbers for the total are about one-and-a-half times higher than shown.

\#\# Emergency caesarean section includes caesarean section where the onset of labour was not stated. 


\section{Birth weight}

Since 2002, the rate of low birth weight (less than 2,500 grams) in Aboriginal and Torres Strait Islander babies has been over 10 per cent and was 12.4 per cent in 2006 (Table 79). This is about one and a half times the rate for babies born to non-Aboriginal or Torres Strait Islander mothers, which was 6.2 per cent in 2006. In 2006, the largest number of low birth weight babies was born in the Hunter and New England Area (Table 80).

\section{TABLE 79}

WEIGHT OF ABORIGINAL AND TORRES STRAIT ISLANDER BABIES, NSW 2002-2006\#

Birth weight (grams)

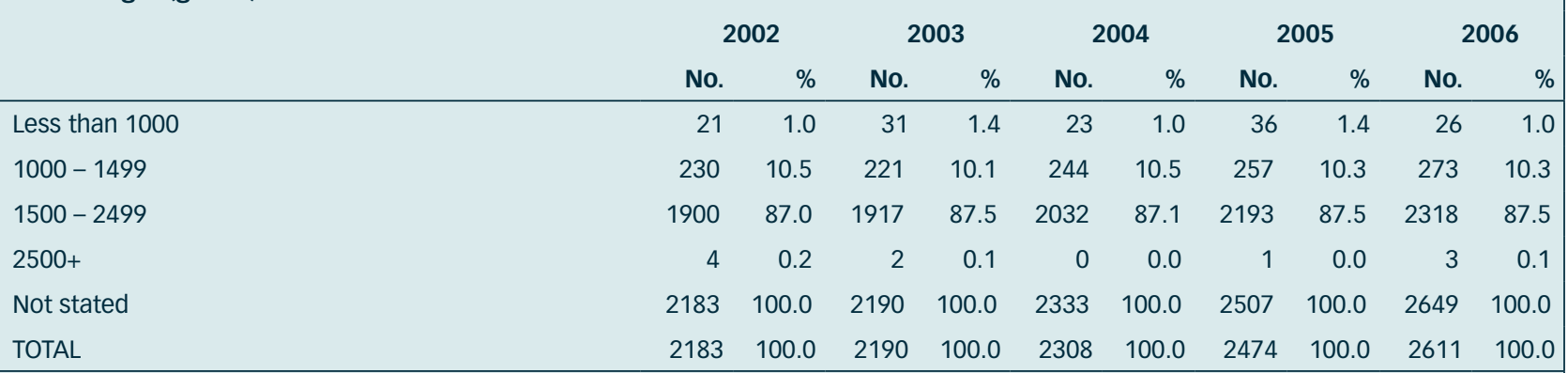

Source: NSW Midwives Data Collection, Centre for Epidemiology and Research, NSW Department of Health.

\# Due to under-reporting of Aboriginality to the MDC, it is likely that the true numbers are about two times higher than shown.

\section{TABLE 80}

\section{WEIGHT OF ABORIGINAL AND TORRES STRAIT ISLANDER BABIES BY HEALTH AREA OF RESIDENCE, NSW 2006\#}

Health Area

Birth weight (grams)

\begin{tabular}{|c|c|c|c|c|c|c|c|c|}
\hline & Less & 2500 & 250 & lus & Not & & & TAL \\
\hline & No. & $\%$ & No. & $\%$ & No. & $\%$ & No. & $\%$ \\
\hline Sydney South West & 34 & 15.7 & 182 & 84.3 & 0 & 0.0 & 216 & 100.0 \\
\hline South Eastern Sydney \& Illawarra & 35 & 15.0 & 198 & 85.0 & 0 & 0.0 & 233 & 100.0 \\
\hline Sydney West & 25 & 8.8 & 260 & 91.2 & 0 & 0.0 & 285 & 100.0 \\
\hline Northern Sydney \& Central Coast & 14 & 13.1 & 93 & 86.9 & 0 & 0.0 & 107 & 100.0 \\
\hline Hunter \& New England & 82 & 13.6 & 519 & 86.1 & 2 & 0.3 & 603 & 100.0 \\
\hline North Coast & 41 & 10.0 & 371 & 90.0 & 0 & 0.0 & 412 & 100.0 \\
\hline Greater Southern & 20 & 10.2 & 177 & 89.8 & 0 & 0.0 & 197 & 100.0 \\
\hline Greater Western & 74 & 13.0 & 494 & 86.8 & 1 & 0.2 & 569 & 100.0 \\
\hline Other/Not stated & 3 & 11.1 & 24 & 88.9 & 0 & 0.0 & 27 & 100.0 \\
\hline TOTAL & 328 & 12.4 & 2318 & 87.5 & 3 & 0.1 & 2649 & 100.0 \\
\hline
\end{tabular}

Source: NSW Midwives Data Collection, Centre for Epidemiology and Research, NSW Department of Health.

\# Due to under-reporting of Aboriginality to the MDC, it is likely that the true numbers for the total are about two times higher than shown. The level of under-reporting varies between health areas (Table 67). 


\section{Gestational age}

Since 2002, over 10 per cent of Aboriginal and Torres Strait Islander babies have been premature (less than 37 weeks gestation) (Table 81 ). The rate of prematurity was 10.8 per cent in 2006 - compared with a rate of 7.3 per cent for babies born to non-Aboriginal or Torres Strait Islander mothers. In 2006, the largest number of premature babies was born in the Hunter and New England Area (Table 82).

\section{TABLE 81}

GESTATIONAL AGE OF ABORIGINAL AND TORRES STRAIT ISLANDER BABIES, NSW 2002-2006\#

Gestational age (weeks)

\begin{tabular}{|lrrrrrrrrrr} 
& \multicolumn{2}{c}{2002} & \multicolumn{2}{c}{2003} & \multicolumn{2}{c}{2004} & \multicolumn{2}{c}{2005} & \multicolumn{2}{c}{2006} \\
& No. & $\%$ & No. & $\%$ & No. & $\%$ & No. & $\%$ & No. & $\%$ \\
\hline $20-27$ & 21 & 1.0 & 29 & 1.3 & 31 & 1.3 & 30 & 1.2 & 24 & 0.9 \\
$28-31$ & 34 & 1.6 & 30 & 1.4 & 29 & 1.2 & 27 & 1.1 & 26 & 1.0 \\
$32-36$ & 212 & 9.7 & 206 & 9.4 & 212 & 9.1 & 244 & 9.7 & 235 & 8.9 \\
$37-41$ & 1868 & 85.6 & 1878 & 85.8 & 2038 & 87.4 & 2180 & 87.0 & 2330 & 88.0 \\
$42+$ & 45 & 2.1 & 47 & 2.1 & 23 & 1.0 & 26 & 1.0 & 31 & 1.2 \\
Not stated & 3 & 0.1 & 0 & 0.0 & 0 & 0.0 & 0 & 0.0 & 2 & 0.1 \\
<20 & 0 & 0.0 & 0 & 0.0 & 0 & 0.0 & 0 & 0.0 & 1 & 0.0 \\
TOTAL & 2183 & 100.0 & 2190 & 100.0 & 2333 & 100.0 & 2507 & 100.0 & 2649 & 100.0 \\
\hline
\end{tabular}

Source: NSW Midwives Data Collection, Centre for Epidemiology and Research, NSW Department of Health.

\# Due to under-reporting of Aboriginality to the MDC, it is likely that the true numbers are about two times higher than shown.

\section{TABLE 82}

\section{GESTATIONAL AGE OF ABORIGINAL AND TORRES STRAIT ISLANDER BABIES BY HEALTH AREA OF RESIDENCE,} NSW 2006\#

\begin{tabular}{|c|c|c|c|c|c|c|c|c|}
\hline \multirow[t]{3}{*}{ Health Area } & \multicolumn{8}{|c|}{ Gestational age (weeks) } \\
\hline & \multicolumn{2}{|c|}{ Less than 37} & \multicolumn{2}{|c|}{ 37-plus } & \multicolumn{2}{|c|}{ Not stated } & \multicolumn{2}{|c|}{ TOTAL } \\
\hline & No. & $\%$ & No. & $\%$ & No. & $\%$ & No. & $\%$ \\
\hline Sydney South West & 36 & 16.7 & 180 & 83.3 & 0 & 0.0 & 216 & 100.0 \\
\hline South Eastern Sydney \& Illawarra & 32 & 13.7 & 201 & 86.3 & 0 & 0.0 & 233 & 100.0 \\
\hline Sydney West & 28 & 9.8 & 257 & 90.2 & 0 & 0.0 & 285 & 100.0 \\
\hline Northern Sydney \& Central Coast & 11 & 10.3 & 96 & 89.7 & 0 & 0.0 & 107 & 100.0 \\
\hline Hunter \& New England & 79 & 13.1 & 524 & 86.9 & 0 & 0.0 & 603 & 100.0 \\
\hline North Coast & 28 & 6.8 & 383 & 93.0 & 1 & 0.2 & 412 & 100.0 \\
\hline Greater Southern & 10 & 5.1 & 187 & 94.9 & 0 & 0.0 & 197 & 100.0 \\
\hline Greater Western & 59 & 10.4 & 509 & 89.5 & 1 & 0.2 & 569 & 100.0 \\
\hline Other/Not stated & 3 & 11.1 & 24 & 88.9 & 0 & 0.0 & 27 & 100.0 \\
\hline TOTAL & 286 & 10.8 & 2361 & 89.1 & 2 & 0.1 & 2649 & 100.0 \\
\hline
\end{tabular}

Source: NSW Midwives Data Collection, Centre for Epidemiology and Research, NSW Department of Health.

\# Due to under-reporting of Aboriginality to the MDC, it is likely that the true numbers for the total are about two times higher than shown. The level

of under-reporting varies between health areas (Table 67). 


\section{Apgar score}

In 2006, 2.3 per cent of Aboriginal and Torres Strait Islander babies had an Apgar score less than seven (Table 50 ), slightly higher than the rate of 2.0 per cent for babies born to non-Aboriginal or Torres Strait Islander mothers.

\begin{tabular}{|c|c|c|c|c|c|c|c|c|c|c|}
\hline \multirow[t]{3}{*}{ Apgar score at 5 minutes } & \multicolumn{10}{|c|}{ Year } \\
\hline & \multicolumn{2}{|c|}{2002} & \multicolumn{2}{|c|}{2003} & \multicolumn{2}{|c|}{2004} & \multicolumn{2}{|c|}{2005} & \multicolumn{2}{|c|}{2006} \\
\hline & No. & $\%$ & No. & $\%$ & No. & $\%$ & No. & $\%$ & No. & $\%$ \\
\hline $0-4$ & 38 & 1.7 & 42 & 1.9 & 34 & 1.5 & 42 & 1.7 & 36 & 1.4 \\
\hline $5-6$ & 31 & 1.4 & 30 & 1.4 & 34 & 1.5 & 33 & 1.3 & 24 & 0.9 \\
\hline $7+$ & 2104 & 96.4 & 2109 & 96.3 & 2256 & 96.7 & 2416 & 96.4 & 2571 & 97.1 \\
\hline Not stated & 10 & 0.5 & 9 & 0.4 & 9 & 0.4 & 16 & 0.6 & 18 & 0.7 \\
\hline TOTAL & 2183 & 100.0 & 2190 & 100.0 & 2333 & 100.0 & 2507 & 100.0 & 2649 & 100.0 \\
\hline
\end{tabular}

\section{Perinatal mortality}

Since 2006, the perinatal mortality rate among Aboriginal and Torres Strait Islander babies has varied from 11.0 to 15.2 per 1,000 births (Table 84 ). The rate of 12.1 per 1,000

in 2006 is substantially higher than the rate of 8.7 per 1,000 experienced by babies born to non-Aboriginal or Torres Strait Islander mothers.

\section{TABLE 84}

PERINATAL DEATHS AMONG ABORIGINAL AND TORRES STRAIT ISLANDER BABIES, NSW 2002-2006\#

\begin{tabular}{|c|c|c|c|c|c|c|c|c|c|c|}
\hline \multirow[t]{3}{*}{ Perinatal deaths } & \multicolumn{10}{|c|}{ Year } \\
\hline & \multicolumn{2}{|c|}{2002} & \multicolumn{2}{|c|}{2003} & \multicolumn{2}{|c|}{2004} & \multicolumn{2}{|c|}{2005} & \multicolumn{2}{|c|}{2006} \\
\hline & No. & $\begin{array}{l}\text { Rate/ } \\
1000\end{array}$ & No. & $\begin{array}{r}\text { Rate/ } \\
1000\end{array}$ & No. & $\begin{array}{l}\text { Rate/ } \\
1000\end{array}$ & No. & $\begin{array}{l}\text { Rate/ } \\
1000\end{array}$ & No. & $\begin{array}{c}\text { Rate/ } \\
1000\end{array}$ \\
\hline Stillbirth & 18 & 8.2 & 24 & 11.0 & 20 & 8.6 & 22 & 8.8 & 16 & 6.0 \\
\hline Neonatal death & 6 & 2.7 & 9 & 4.1 & 7 & 3.0 & 16 & 6.4 & 16 & 6.0 \\
\hline TOTAL PERINATAL DEATHS & 24 & 11.0 & 33 & 15.1 & 27 & 11.6 & 38 & 15.2 & 32 & 12.1 \\
\hline
\end{tabular}

Source: NSW Midwives Data Collection, Centre for Epidemiology and Research, NSW Department of Health.

\# Perinatal deaths include deaths reported to the MDC only. As the MDC form is completed at discharge or transfer of the baby, deaths occurring after this time may not be reported to the MDC. Due to under-reporting of Aboriginality to the MDC, it is likely that the true numbers are about two times higher than shown. The level of under-reporting varies between health areas. 